\title{
Which differences? Notes for a project on Sicilian and Andalusian grammarians
}

\author{
MiRella CASSARINO (Università degli Studi di Catania) \\ ANTONELLA GHERSETTI (Università Ca’ Foscari Venezia)
}

\section{Andalusian and Sicilian grammarians ${ }^{1}$}

In an important article titled "The Andalusian Grammarians, are they different?," Michael Carter turned his attention to the detectable peculiarities in the grammatical thought of alAndalus that he took as being representative of the entire Maghrib area:

Following the practice of those less familiar with this part of the Arab world than Ibn Khaldūn, we shall take al-Andalus as standing for the whole maghrib (henceforth Maghrib), as the "West", a single geographical unit embracing both the African and the Spanish domains between which scholars moved freely. However, a chronological division will be made between al-Andalus under the Umayyads (139423/756-1031) and al-Andalus under the subsequent régimes up to the Reconquista of 1492. The two periods are highly asymmetric, but the qualitative difference between them is equally extreme. ${ }^{2}$

The grammarians of the Arab West, above all those active in the Umayyad epoch, such as al-Qālī (d. 356/967), went for their training to famous schools in the East where they acquired their knowledge, in a spirit of emulation and competition, before spreading it through their teachings in their lands of origin where there was a strong felt need of normalizing the language. ${ }^{3}$ In his article, Carter dwells on the existing differences between $a h l$ al-Mašriq and ahl al-Magrib, both in the approaches and in the terms used ${ }^{4}$-it seems that in the West the use of mnemonic processes of knowledge acquisition was prevalent, to the

1 In this article pages 67-74 and the Bibliography are by Mirella CASSARINO, pages 74-76 by Antonella GHERSETTI. We wish to express our gratitude to the editors, Lutz Edzard and Stephan Guth, for having accepted to publish this special section on Arab-Sicilian and Andalusian Grammarians in the Journal of Arabic and Islamic Studies. The essays contained in it are the fruit of the reworking of some of the papers presented at the $28^{\text {th }}$ Conference of the Union Européenne des Arabisants et Islamisants (Palermo, 12-15 September 2016) in the frame of the panel "Arab-Sicilian and Andalusian Grammarians".

2 CARTER 2012: 31.

3 This is demonstrated in the experience of Șa $\bar{a}^{c} i d$ b. al-Ḥasan al-Raba ${ }^{c} \overline{1}$ (d. 1026), who travelled from Baghdad to the Maghrib because in that area of the Arab world there was a felt need of "luga". See CARTER 2012: 32 e n. 5.

4 CARTER 2012: 40-43.

Journal of Arabic and Islamic Studies 17 (2017): 67-78 (C) Mirella Cassarino, Università degli Studi di Catania / Italy Antonella Ghersetti, Università Ca' Foscari Venezia / Italy 
detriment of comprehension - both in juridical and theological schools and this had important effects on grammatical methods. ${ }^{5}$ It is enough to consider the well-known case of the Andalusian grammarian Ibn Maḍāa al-Qurțubī (d. 591/1196), ${ }^{6}$ who belonged to the zāhirī school that promoted an approach to texts free of personal interpretations $\left(r a^{3} y\right)$ and of the imitation of authoritative models (taqli $d$ ). This grammarian, rejecting in absolute terms the concept of linguistic causality ${ }^{7}$ and bringing into discussion the grammatical theory of regency (nazariyyat al-'amil), ${ }^{8}$ was the protagonist of a process of reform and of simplification of the Arab linguistic tradition, already felt as necessary by many of his predecessors. ${ }^{9}$ Other aspects that seem to have characterized Andalusian grammarians, in particular those active between the end of the Umayyad epoch and the Reconquista, were a striking individualism and a particular eccentricity: this was the case, for example, of Talla al-Munağğim, a contemporary of al-Zubaydī (d. 379/989), of Muhammad b. Yaḥyà alRabāḥī (d. 358/968) and of others, usually described as strange or solitary spirits. ${ }^{10} \mathrm{We}$ might add to the grammarians mentioned by Carter references to grammarians from Sicily who undoubtedly gravitated in the Maghrib orbit and had contact with the learned men of al-Andalus.

It is not superfluous to recall here (with the aim of better framing the question of relations between Sicilian and Andalusian grammarians) that the duration of the Islamic presence in the two areas of the Arab-Islamic West was very different. Sicily, situated at the centre of the Mediterranean, was conquered, Arabized and Islamicized somewhat later compared to other areas of the Western Mediterranean (827-965). Indeed it entered to form part of the Dār al-Isläm from the ninth century onwards and remained within it for a relatively brief period of time. The Christian reconquest of the island by the Normans began as early as 1061, a fact that had prevented the constitution of a strong power such as that of the Umayyads in Spain. The Islamic conquest of Spain, on the other hand, began as is known with the landing in Gibraltar in 711, and continued with the foundation of the Emirate of Cordoba in 753 and then concluded with the foundation of the Umayyad caliphate of al-Andalus in 929. In 1031 the Mulūk al-Ṭawā'if epoch began. In Spain the reconquest went through alternating phases and periods of stasis and the last Moorish realm, Granada, was taken in 1492. The advent of the Normans in Sicily generated an exodus of the island's intellectual elite (and thus of grammarians too), above all towards al-Andalus where they

\footnotetext{
5 It is not by chance that the Arab biographical dictionaries usually indicate the affiliation of grammarians to a given juridical school. We know, for example, that the Andalusian Ibn Hazm (d. 456/1064) was zāhirī and that for this reason he rejected the istihsān (a term translatable with juridical preference or legal equity) - a concept that grammar borrowed from the law-and which Ibn al-Anbārī (d. 577/1181) on his part, belonging to the šafíi ì school, considered with suspicion. The istihsāan was probably accepted by the Hanafites.

6 On this Andalusian grammarian I suggest WOLFE 1990: 295-306; VERSTEEGH 2013: 207-232.

7 CARTER 2012:34

8 CAmpanelli 2016.

9 Considerable attention is given to this matter in the as yet unpublished doctoral thesis of Marta Campanelli, Complessità ed astrattezza della tradizione linguistica araba: la teoria della reggenza e la contestazione di Ibn Mad̄ â al-Qurțubi (presented at the University of Rome La Sapienza in 2016).

10 CARTER 2012: 35-40
}

jais. 17 (2017): 67-78 
found refuge in the courts of the Iberian peninsula. This was, inevitably, a unidirectional migration that marked the end of reciprocal cultural exchange. In al-Andalus, as the research carried out for example by Salvador Peña, ${ }^{11}$ Francesco Binaghi, ${ }^{12}$ and Marta Campanelli ${ }^{13}$ demonstrates, grammatical production continued to be abundant and at times particular. It is enough to consider the results presented by those scholars who edited the ECA, the Enciclopedia de la Cultura Andalusi ${ }^{14}$ to realise the number of linguists and grammarians who were active there, but who no longer had anything in common with Sicilian production, given that the island was by that time out the orbit of Islam.

\section{Sicily, al-Andalus and the "hidden aspects"}

Arab sources, especially historical and prosopographic sources, provide us with glimpses of how the relations between learned men of al-Andalus and Sicily during the ninth and tenth centuries were rather intense and productive both in circles more directly connected to religious sciences as a whole and in what we might call "lay" circles. ${ }^{15}$ As authoritative scholars of Islamic Sicily have already usefully observed, "It proves extremely difficult, with regard to intellectuals from al-Andalus and Sicily, to say which was a greater influence on the other". ${ }^{16}$ It is enough here, and for reasons of available space, to mention some significant examples. So let us consider, as far as Quranic studies are concerned, the case of Ḩalaf b. Ibrāhīm al-Qurțubī b. al-Ḥaș̦āan, muqrì from al-Andalus, who died in 1117 and was a pupil, in Sicily, of Muhammad b. 'Alī al-Azdī, known for being one of the most famous $q \bar{a} r i^{\prime}$ of the island ${ }^{17}$ and the case of various Andalusian scholars who, on Spanish soil, studied under the guide of a Sicilian master, i.e. 'Abd al-Ḥaqq b. Hārūn al-Șiqillī. ${ }^{18}$ And again in the field of 'ilm al-qirāa ât, we note how Ahmad b. Muhammad b. Halaf b. Muhriz al-Anșārī al-Šațībī al-Andalusī was a pupil both of 'Alī b. Muḥammad b. Hammūšs al-Șiqillī, and of Ibn al-Faḥhām al-Șiqillī (1030-1122), albeit in Egypt this time and, to be precise, in Alexandria. It is indeed to Ibn al-Fahhām that we owe the glosses to a wellknown grammar text composed by Ibn Babašăd (469/1077) of whom he was a pupil in Cairo together with Halaf b. Ibrāhīm, he too a conveyor of the master's work. ${ }^{19}$

Definite reciprocity in cultural exchange is also to be found in the field of prophetic traditions. We know, indeed, that Muhammad b. Muslim al-Qurašī al-Mazarī al-Ṣiqillī (he died in Alexandria in 1135) trained under the guidance of Abū Bakr Muhammad al-

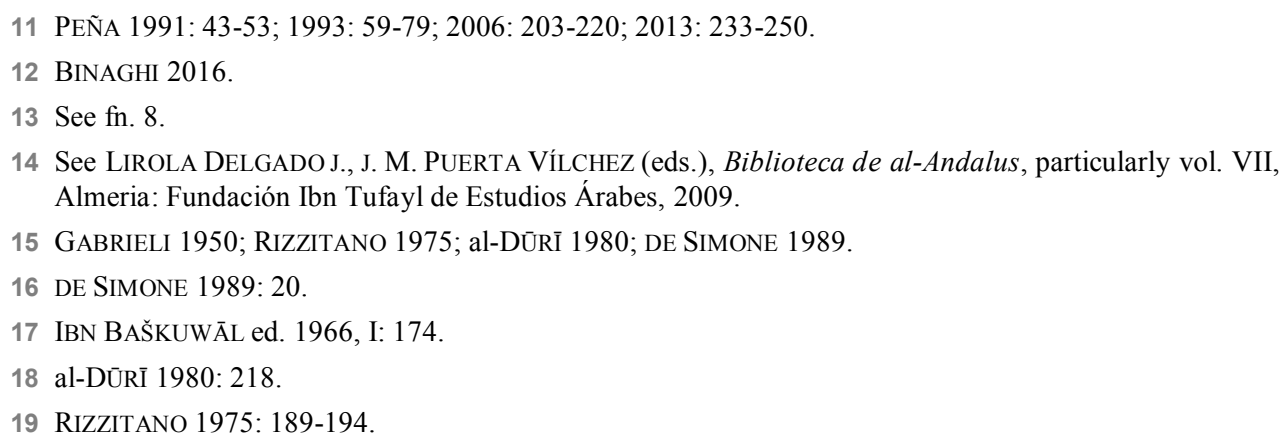


Țurțūšs̄i, ${ }^{20}$ just as the traditionalist of Murcia Muhammad b. Yūnus b. Sa āāa, who was faqīh and $q \bar{a} \hat{d} \bar{l}$ at one and the same time, was a pupil of the most celebrated of the Imām alMazarī. ${ }^{21}$ And now we come to some examples relating to the field that interests us here, the grammatical and lexical area. The sources give us the name of Ibn al-Birr al-Siqilli, born in Sicily towards the end of the tenth century, and who, after having studied in Alexandria - we find him there in 1024 - and then in Mahdiya, returned at the end of the Kalbite period, when Sicily was torn by the conflicts between the four $q \bar{a} \mathrm{i} i d$ who contested domination of the island. ${ }^{22}$ It was one of these, Ibn Mankūd, who warmly welcomed him to Mazara, the city in which Ibn al-Birr practised his teachings and where he also had occasion to meet Ibn Rašīq al-Qayrawān̄i (d. 418/1027-28). From Mazara the philologist was obliged to move to Palermo, where he continued his activity as teacher and where he remained until 1068. Arab sources do not provide the titles of his works, but they do grant him some achievements, paramount his having transmitted al-Ğawharı̄'s dictionary to his pupil Ibn al-Qatțā $\bar{c}^{-}$, who, it seems, then disseminated it in Egypt. We also owe to him his having contributed to the survival of the poetic tradition of al-Mutanabbī (d. 355/965) not only in Sicily, but also in Egypt where he lived in exile after the arrival of the Normans. Lastly, it seems that he carried out the revision of the work of lahn al-' $\bar{a} m m a$ by Ibn Makki al-Siqillī, which will receive attention below. We also find, among the others active in Sicily, the Andalusian Șā̄id b. al-Hasan al-Raba'̄i (d. 417/1026), not by chance nicknamed al-lugiawī. This last, following the death of the hăğib (chamberlain) al-Manșūr b. Abi 'Amir, royal lord of al-Andalus from 978 to 1002, whose teacher he had been together with Abū 'Alī al-Qālī e Ibn al-Qūtiyya, left Spain to travel to the Kalbite court in Sicily. From there he travelled again to Cordoba, before passing away on our island during a further journey. $\mathrm{Sa}^{\mathrm{c}} \overline{1} \mathrm{~d}$ b. Fathūn al-Qurțub̄̄, another grammarian, was instead active in Sicily right up to his death. He was an expert in metrics, in music and philosophy and it is to him that we owe the editing of a Kitāb al-'af'āl that was to have some role in the training of Ibn alQatțā and in the writing of his homonymous work. ${ }^{23}$ This was organized as a compendium and comment to the Kitāb al-'af'āl of Ibn al-Qūtiyya al-Qurțubī (d. 367/977), of which a manuscript copy exists, held in the Lucchesiana Library in Agrigento. With the advent of the Normans on the island, Ibn al-Qatțā indeed emigrated to Andalusia. We find him having been welcomed to the court at Zaragoza (testified in a rhymed prose epistle that has come down to us), where the Banū Hūd dynasty had supplanted the Banū Tuğîib dynasty in governing the city. From there he moved in the end to Egypt where he probably arrived with the fame of his writings having preceded him. Here he became educator to the children of the wazìr al-Afdal and taught metrics, grammar and lexicography successfully. The double name of al-Șiqillī and al-Mișrī that is sometimes attributed to him by biographers and the great numbers of pupils who in Egypt acquired and transmitted his writings is tes-

\footnotetext{
20 al-DŪRĪ 1980: 213.

21 BORRUSO 1983: 33-43.

22 RizzitAnO, “Ibn al-Birr”. In: Encyclopaedia of Islam, Second Edition, Edited by: P. Bearman, Th. Bianquis, C.E. Bosworth, E. van Donzel, W.P. Heinrichs. Consulted online on 06 October 2017 $<$ http://dx.doi.org/10.1163/1573-3912_islam_SIM_3117>; DE SIMONE: 20.

23 DE SIMONE: 21.
}

jais • 17 (2017): 67-78 
timony to the success and the importance of his work. ${ }^{24}$ I feel it is important to make reference here to another network of evident relations: if there is indeed no doubt, given that we find it declared in the Tatqīf al-lisānn, that the work of al-Zubaydī al-Išbīlī (m. 379/989) was fundamental for the writing of the Tataīf al-lisān of Ibn Makkī al-Șiqillī (d. 507/1107), ${ }^{25}$ it is also true that the grammarian al-Zubaydī had been a pupil, in his turn, of other Sicilian masters, of Abū 'Imrān al-Șiqillī and Abū 'l-Ḥasan 'Alī b. al-Billanūbī al-Ṣiqillī. Textual relations (this is a more recent acquisition) exist between the work al-Madhal ilà taqwìm al-lisān wa ta'lim al-bayān by the Andalusian Ibn Hišām al-Lahmī and those of lahn al'āmma by his two predecesors, al-Zubaydī e Ibn Makkī. The work of Ibn Hišām al-Lahmī̄, published by José Pérez Lázaro in 1990, indeed opens with two brief polemical texts, not by chance titled Radd 'alà al-Zubaydī (Confutation against al-Zubaydī), and Radd 'alà Ibn Makki (Confutation against Ibn Makkī), ${ }^{26}$ in which he rectifies some deviations from the norm recorded by his predecessors. Also to be borne in mind is the fact that both alZubaydī and al-Qālī, who attracted the interest of Ibn Hazm of Cordoba (d. 456/1064), perhaps due to the absence in the works of both men of any form of speculative thought on language, ${ }^{27}$ were active in the court of the first Andalusian Umayyad caliph 'Abd alRaḥmān al-Nāșir. ${ }^{28}$ Both probably represented, as Salvador Peña has observed, "the official trend of linguistics in al-Andalus at the time, being very well acquainted with each other". ${ }^{29}$ It therefore seems that in no way did al-Qālī, pupil in Baghdad of Ibn Durustuwayhi (d. 347/958), of Ibn Durayd (d. 323/934) and of Ibn al-Sarrāğ (d. 316/928) seek a role in the transmission to the West of the innovative ideas in the linguistic-grammatical field expressed, as is known, by what is called the School of Baghdad. Furthermore, among the pupils of the grammarian al-Zağğgağī (d. 337/949), we find Abū 'Alī al-Ḥasan b. 'Alī b. Ibrāhīm al-Ṣiqillī al-Dimašqī al-Naḥwī, who died in Mecca immediately after having completed his pilgrimage. He was born in Sicily and also became a grammarian and poet. ${ }^{30}$ It is not inappropriate to recall, apropos of differing tendencies that were already forming in alAndalus, that Ibn Ğundal (d. 401/1011), in his commentary on the Kitāb di Sībawayhi, ${ }^{31}$ confuted al-Zubaydī and went well beyond the transmission of data or of simple models of prescriptive grammar. ${ }^{32}$

The examples given, far from being comprehensive, do however give the idea of the depth and the intensity of relations between the scholars with linguistic interests of Șiqilliyya and of al-Andalus. They also demonstrate how the weave of relations extended well beyond these two areas of the Maghrib and touched the entire Arab-Islamic world of

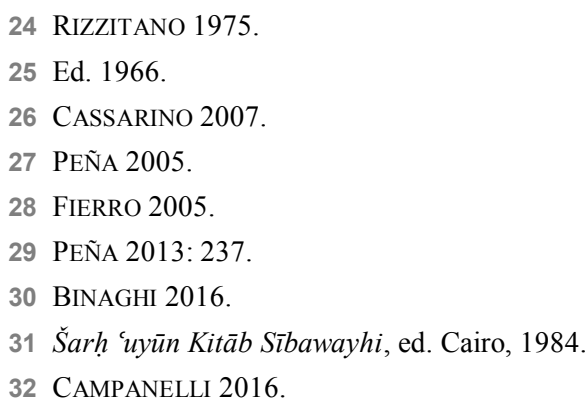


that time. ${ }^{33}$ Only an in-depth knowledge of these relations, corroborated by textual analysis, might allow for a more correct and nuanced reconstruction of both Western grammatical thought and of the more comprehensive developments of linguistic science disciplines in the Arab-Islamic East and West.

\section{New elements in research}

Relations of a historical, political, social and cultural nature between Muslim Sicily and alAndalus in the broad sense have been the object of various studies for some time. These enquiries have aimed above all at tracing, in comparative terms, elements of commonality and difference characterizing the Islamic conquest and presence in the two jaziras. ${ }^{34}$ The theme in question, the study of political, economic and cultural contact between the two areas over the course of their Islamic history and beyond, has indeed enjoyed renewed interest. Proof of this is the conference recently held in Barcelona with the title, "Sicily, alAndalus and the Maghreb: Writing in Times of Turmoil", which sought, in interdisciplinary terms and also through the filter of literary production, to deal with the effects of conflict, processes of exclusion or inclusion, of knowledge sharing that took place during periods of crisis, of disorder and of changes in power in the areas indicated. ${ }^{35}$ Even in the case of this academic initiative, however, as has happened in the past, the role of the linguistic disciplines and more precisely the grammar was marginal, even although they occupy a central position in the Arab-Islamic tradition. To take an interest in language, it is worth emphasizing, means to use it as a point of departure for reflection and to reach an analysis for understanding culture and human relations in their complexity. ${ }^{36}$ Thus, after brief and preliminary notes on some particular linguistic-grammatical developments in the Maghrib, ${ }^{37}$ I have mentioned some relations, still to be explored, that existed in the ninth and tenth centuries between the grammarians of Sicily and those of al-Andalus. I will now raise some questions that the research group formed during the occasion of the $28^{\text {th }}$ conference of the Union Européenne des Arabisants et Islamisants on an initiative by Antonella Ghersetti and myself, will be able to direct its attention to over the course of its future research. ${ }^{38}$ The research group's aim, in essence, is to study Arab texts of a linguistic-

33 Al-DŪRĪ correctly makes reference to the "Mediterranean" dimension of Sicily.

34 See GABRIELi 1950: 27-45; RizZITANO 1975: 551-65; DE SiMONE 1989: 17-38; GUICHARD 1990; KENNEDY 1995: 646-69; MANDALÀ 2012: 43-54.

35 The conference, organized by Nicola Carpentieri and by the Department of Medieval and Ancient Studies, took place between 4-5 May 2017 at the Universitat Autònoma de Barcelona. The proceedings are currently at press.

36 EDZARD \& WATSON (eds.) 2006.

37 MuṬLAQ 1967; CARTER 2012: 31-48.

38 The panel "Arab-Sicilian and Andalusian Grammarians", conceived and coordinated by Antonella Ghersetti and myself, saw interventions from Francesco Binaghi, Oriana Capezio, Mirella Cassarino, Francesco Grande and Cristina La Rosa. The group's work, thanks to the initiative of Cristina La Rosa and Francesco Grande, then led to another two meetings, both dedicated to the "Circulation and transmission of Arab grammatical thought in Sicily and al-Andalus" in which other scholars took part with 
grammatical nature produced in Spain and in Sicily, this last being a context much less explored than the Andalusian one. Eventual elements of difference will be acknowledged, but so too will the common processes of development in the field of what is defined as the Arab linguistic tradition. ${ }^{39}$

\section{Open questions}

Naturally a series of questions - preannounced in the title of this preface and to which I will now make reference-must be taken into consideration. In the wake of suggestions arising from linguistic studies concerning other areas, I would like to begin precisely with the relevant chronological arc and geographical picture. If the former can on the whole be limited to the Islamic presence in the two jaziras, which was, as is known, much longer and more rooted in the Iberian peninsula, the geographical picture should, in my opinion, include other areas, precisely because of the nature and the modalities of transmission and circulation of knowledge in Islam. In our case the objective is to include, in the widest allinclusive picture, the work of Sicilian and Andalusian grammarians in order to understand the role that they fulfilled (this is particularly valid for the "Sicilians" that up to now have been less studied). These role and impact may also emerge from a simple examination of the pages of the Mư̆ğam al-'ulamā’ wa'l-šu'arā' al-șiqilliyyīn by Iḥsān 'Abbās. ${ }^{40}$ And this, even if the single works, various grammatical commentaries, lahn al- 'َamma writings, garīb treatises, thematic lexicons (mubawwab) are explained and justified in the specific context that produced them, sometimes an extremely limited context, as in the case of polemical texts or those regarding amendments to the language.

An important aspect, methodological in nature, that must be borne in mind regards the extent of the field covered by the discipline. The works cited in the part relative to relations between Andalusian grammarians and Sicilian grammarians are almost always not works of "grammar" in the strict sense. We find ourselves, for example, dealing with grammatical commentaries concerning Mutanabbian verses, with small treatises on metrics, didactic manuals, laḥn al-'ämma texts. Also to be borne in mind is the complexity of the linguistic substrate in Sicily and in al-Andalus. After all, it is a well-known fact that the philologicalgrammatical disciplines are linked and that they share with law the same modality, i.e. the principle of divergence of thought and the practice of discussion, deriving from the very constitution of the schools. ${ }^{41}$ The idea, therefore, of turning our attention not only to disciplines and texts that are grammatical, but also to texts of linguistic and philological character could lead to interesting results: commentaries on poetry, linguistic-grammatical tafsīr, lexicons, etc. The contributions presented here constitute a first step in this direction.

their own contributions, including Antonella Ghersetti and Marta Campanelli. The first of these took place at the Department of Humanities of the University of Catania (4-5 April 2017), the second took place at the Department of Asian and North African Studies at the University Ca' Foscari, Venice, on 15-16 November 2017.

39 Bohas / Guillaume / Kouloughli 1990; Versteegh 1997; BAAlBAKi (ed.) 2007; ID. 2014.

40 'ABBĀS 1994.

41 CARTER 2011. 
In the light of progress made in the field of linguistic studies, attention should also be brought to bear on the aims of single works, on the various generations of grammarians ${ }^{42}$ and on their horizons of expectations. We can adopt, beginning with the texts (some of which are published, others still await critical editions), both a general theoretical approach and more specific perspectives that allow us to bring into focus philological problems relating to individual texts or texts that interpret particular moments of given traditions. The approach adopted by Salvador Peña with regard to the work of various Andalusian grammarians can, in my opinion, be an example for our current and future research, above all if combined with welcome collaboration with Arab scholars interested in publishing the Arab linguistic-grammatical heritage.

The questions that will have to be dealt with regarding relations between Sicily and alAndalus in the field that interests us here are various and are very complex. For example, the question of the presumed "peripheral" nature of the Maghrib and the consequences that this is supposed to have had on the teaching/learning of Arabic and on the activity of the grammarians. ${ }^{43}$ Ibn Haldūn expressed himself clearly on this with regard to education, which also involves the philological disciplines, he makes a clear distinction between Mashriq and Maghrib. He even writes of the "degeneration" of grammar, although he extends his reflection to the entire Arab-Islamic area. ${ }^{44}$ Equally important is the question that has its point of departure in the development of grammatical studies, in an initial phase directed at the codification and systemizing of all the material derived from pre-Islamic sources and from the Quran, but which from the tenth century onwards was increasingly connected to humanistic logic and culture. In other words, how much of all this is it possible to perceive in the work of the grammarians of Sicily and of al-Andalus?

\section{First results}

The papers of this monographic dossier focus on Ibn al-Qattāa (d. 515/1121). This is a prominent personality in the field of linguistic and philological studies in Muslim Sicily whose scholarly production seems to have been understudied, with some exceptions, until today. The essays contained in this section are thus intended as a timely contribution to a better assessment of Ibn al-Qatța ${ }^{c}$ 's role in the development of linguistic and philological studies in Muslim Sicily, and in the Arab-Islamic empire more generally.

The papers of Capezio, Grande and La Rosa converse with each other, highlighting the multifaceted scholarly profile of this Sicilian man of letters whose biographical details constitute a vivid representation of the intellectual tradition of a big Sicilian family and of its fortune (and/or misfortune) over time. Born and raised in Muslim Sicily, Ibn al-Qatțā

42 See, for example, the paper "Protos euretes in al-Andalus; la prima generazione dei grammatici andalusi nell'opera di al-Zubaydī (m. 379/989)" presented by Antonella Ghersetti to the above mentioned Meeting "Circulation and transmission of Arab grammatical thought in Sicily and al-Andalus" (Catania, 4-5 April 2017). The paper will be published in the Proceedings edited by Francesco Grande and Cristina La Rosa.

43 See, for example, LENTIN 2006-2007 and NEF 2011.

44 See IBN HaLDŪN, ed. 2005, 5: 314-21 (chapter VI, paraghraphs 36-38). 
spent the last part of his life in exile between al-Andalus and Egypt, where he died. Although being in line with the linguistic tradition of the Eastern part of the Arab-Islamic empire, his scholarly activity shows traits of originality in different fields. His works on metrics, on morphology and on literary criticism offer more than one reason of interest in that they point to aspects of novelty in his detailed approach to morphology, in his wideranging analysis of obscure verses of poetry and in his peculiar position in relation to poetic meters and verses serving as textual evidence. The thorough investigation of the manuscript tradition of one of his treatises carried out by Oriana Capezio and the comparison with other treatises of the same genre belonging to the Eastern and Andalusian tradition carried out by Cristina La Rosa also help in assessing the position of Ibn al-Qattạ $\bar{a}^{c}$ as a connection between the two extremities of the Arab-Islamic world.

Kitāb al-Bāri' fì 'ilm al-'arūd, Ibn al-Qatțā' 's treatise on metrics, was held in high esteem by Arab scholars. The peculiarities of this work in comparison with the canons of other similar important treatises are scrutinized in CAPEZIO's piece. Through a thorough investigation of the extant manuscripts, starting from the oldest copy preserved in Cairo (where Ibn al-Qatta $\bar{a}^{-}$died) and dating back to one century after the author's death, Capezio underlines the relevance of Kitāb al-Bāric for the construction of a canon and its wide circulation in the Eastern and Western areas of the Arab world, from Yemen to al-Andalus. Capezio's minute investigation into the different renderings in the manuscript tradition of the text also helps in tracing the itinerary of the text in the Arab world. Although a Sicilian school of metrics properly speaking did not exist, the spread of Kitāb al-Bāric confirms the significance of this Sicilian scholar in the field of philological and literary studies. The manuscript tradition is investigated though the lens of a case study (the meter tawīl) describing the variation of $\breve{s}$ awāhid (verses serving as textual evidence), metrical transcriptions and visual rendering of the prosodic circles. This survey is a cue to the different receptions of Ibn al-Qatțā's treatise and its adaptation to different environments and local traditions. The absence of samples of Sicilian poetry among the šawāhid, though considered deceptive by scholars of the past, can be taken as a hint at his dependence on Eastern and Western canonical works and thus constitute a meaningful element for a better evaluation of his position in the framework of the Arab metrical tradition. Investigation carried out on $\breve{s} a w \bar{a} h i d$, which have a normative value, is particularly apposite since they contribute to the building of a corpus and a canon of poetry, also defining the images of poets considered relevant in a specific period and environment. Capezio thus suggests that Ibn alQatțāa succeeded in establishing a Western corpus building on the Eastern one.

Ibn al-Qatțā's contribution to grammatical studies, with a focus on his treatise on morphology Kitāb 'abniyat al-'asma ', is at the core of GRANDE's paper. This fine-grained enquiry into Ibn al-Qațtā's originality puts forward the hypothesis of his particular, semantically-oriented approach to morphological phenomena. In the meantime, it aims at highlighting traits of novelty in the broader context of the Arab Linguistic Tradition (henceforth ALT), where the main innovative traits would concentrate on the level of meaning. Questioning the common view of the conservatism of ALT and of its tendency to focus on a formal approach to linguistic analysis, Grande's paper attempts to single out a certain degree of novelty in Ibn al-Qațtạ̄'s peculiar approach to morphological phenomena. A similar approach has been investigated in scholarly literature for some Eastern authors like 'Abd al-Qāhir al-Ğurğānī or Rāḍ̂̄ al-Dīn al-Astarābād̄ị, whose positions are briefly summarized 
in this article, but a systematic investigation was still lacking for other authors. Grande's enquiry into semantically-oriented original approaches first expounds on Ibn Hišām's treatment of the article al- based on the notion of 'ahdiyya (previous knowledge), which is analyzed in its triple development. It moves then to the case of Ibn al-Qattāt whose original semantic approach, he explains, can be pinpointed not only in the author's treatment of the mașdar as a self-contained object of investigation, but also in his detailed explication of the morphological pattern of affixation, analyzed in conversation with Síbawayhi's Kitāb on the same point. Grande concludes suggesting that traits of novelty concentrating on the level of meaning in ALT could be rooted in linguistic Quranic exegesis and in its peculiar semantic approach.

LA RoSA's paper focuses on some morphological and lexical issues discussed in Mağmū'a min ši r al-Mutanabbī wa-gawāmiḍihi, Ibn al-Qațțā's commentary on obscure verses by al-Mutanabbī. This title is analyzed in conversation with the commentaries corpus of al-Mutanabbī's poetry and in particular is compared with the analogous works of Ibn Ğinnī and al-Iflīlī. The comparison with them, the first representing the mainstream tradition rooted in al-Mašriq and the second one embodying the Andalusian tradition, aims at offering a better understanding of Ibn al-Qatțā's peculiar features as a grammarian and a philologist in relation with the central position of the Sicilian context. This is a welcome contribution since this scholar's commentary has been until now somehow neglected in favor of his two well-known treatises on morphology. La Rosa's essay, underlining how both Ibn al-Qatțā̄ and al-Iflīlī heavily depend on Ibn Ğinnī’s commentary, helps in better assessing Ibn al-Qatța ${ }^{-}$'s dependence on the Eastern linguistic tradition and characterizes him, although with his own approach focused on syntax and his peculiar terminological choices, as a continuator of Ibn Ğinnī’s tradition in the commentary of al-Mutanabbī. This paper, delving into the analysis of morphological phenomena like ilhāq (adjunction) and tahfif (lightening), and lexical/semantic points treated in the Mağmü ${ }^{c} a$, also cleverly emphasizes the multifaceted intellectual profile of Ibn al-Qatțā and his mastery of grammar, lexicography and literary criticism.

\section{Bibliography}

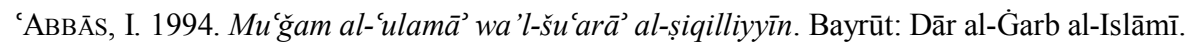

Adang, C. / Fierro, M. / SchmidtKe, S. (eds.). 2013. Ibn Hazm of Cordoba: The Life and Works of a Controversial Thinker. Leiden, Boston: Brill.

BAALBAKI, R. 2014. The Arabic Lexicographical Tradition: Naḥw and șarf. Leiden: Brill.

- (ed.). 2007. The Early Islamic Grammatical Tradition. Aldershot: Ashgate, Variorum.

BinaGHI, F. 2016. La postérité andalouse du Ğumal d'al-Zağğāğğ. Unpublished doctoral thesis discussed in December 2015 at the Université d'Aix-Marseille.

Bohas, G. / Guillaume, J.-P. / DJ. E. Kouloughli, 1990. The Arabic Linguistic Tradition. London: Routledge.

Campanelli, M. 2016. Complessità ed astrattezza della tradizione linguistica araba: la teoria della reggenza e la contestazione di Ibn Maḍa ${ }^{\prime}$ al-Qurțbī. Unpublished doctoral thesis discussed in 2016 at the Università di Roma La Sapienza.

jais • 17 (2017): 67-78 
CARTER, M. G. 2011. “The Andalusian Grammarians, Are They Different?” In Orfali (ed.) 2011: 3148.

CASSARINO, M. 2007. "Una polemica linguistica nel XII secolo: il Radd 'alā Ibn Makkī di Ibn Hišām al-Lahmi””. In Moriggi (ed.) 2007: 9-24.

De Simone, A. 1989a. Nella Sicilia 'araba' tra storia e filologia. Palermo: Luxographica.

—. 1989b. "al-Andalus-Ṣiqilliyya: appunti per una storia culturale del Portogallo". In DE SiMONE 1989a: 17-38.

al-DŪRĪ, T. al-D. 'Ā. 1980. Șiqilliyya: ' 'alāqātuhā bi-duwal al-bahrr al-mutawassiț al-islāmiyya min al-fath al-'arabī hattà al-ġazw al-nurmandī. Bag̉dād: Wizārat al-taqāfa wa'l-i'lām.

EdZARD, L. / WATSON, J. (eds.). 2006. Grammar as a Window onto Arabic Humanism: A Collection of Articles in Honour of Michael G. Carter. Wiesbaden: Harrassowitz.

Fierro, M. 2005. 'Abd al-Rahman III: The First Cordoban Caliph. Oxford: Oneworld Publications.

GABRIELI, F. 1950. “Arabi di Sicilia e Arabi di Spagna”. al-Andalus, 15.1: 27-45.

Guichard, P. 1990. L'Espagne et la Sicile musulmanes aux XI et XII' siècles. Lyon: Presses Universitaires Lyon.

IBN BASKUWAL. Ed. 1966. al-Ṣ̄la. al-Qāhira: al-Dār al-Mișriyya lil-ta'līf wa'l-tarğama.

IBN ĞUNDAL. Ed. 1984. Šarh 'uyūn Kitāb Sībawayhi / ed. 'Abd Rabbih 'Abd al-Lațîf 'Abd Rabbih. alQāhira: Maṭba'at Hassān.

IBN ḨaldūN. Ed. 2005. al-Muqaddima / ed. 'A. al-S. Šaddādī. 5 vols. Dār al-Bayḍā’: Huizānat Ibn Haldūn, Bayt al-funūn wa'l-'ulūm wa'l-ādāb.

IBN MAKKī. Ed. 1966. Tatquîf al-lisānn wa-talqīh al-ğanān / ed. 'A. al-'Azīz Mațar. al-Qāhira: Dār alma ārif.

Kennedy, H. 1995. "Sicily and al-Andalus under Muslim rule”. In Reuter (ed.) 1995, 3: 646-69.

LENTIN, J. 2006-2007. “L'arabe parlé en Sicile était-il un arabe périphérique ?” Romano-Arabica, VIVII: $71-84$

Lirola Delgado, J. / J. M. Puerta vílchez (eds.). 2004-2013. Enciclopedia de la cultura andalusí, Biblioteca de al-Andalus. 7 vols. Almeria: Fundación Ibn Tufayl de Estudios Árabes.

MANDALÀ, G. 2012. "Figlia d'al-Andalus: Due giazira a confronto, Sicilia e al-Andalus, nelle fonti arabo-islamiche del Medioevo". Le forme e la storia, n.s. V: 43-54.

Moriggi, M. (ed.). 2007. XII Incontro di Linguistica camito-semitica. Atti. Soveria Mannelli: Rubbettino.

MuṬLAQ, A. Ḥ. 1967. al-Harakāt al-lugiawiyya fì 'l-Andalus mundu 'l-fath al- 'arabì hattà nihāyat 'aṣr mulūk al-țawā'if. Șaydā, Bayrūt: al-Maktaba al-mișriyya.

NeF, A. 2011. Conquérir et gouverner la Sicile islamique aux XI et XII siècles. Rome: École française de Rome.

Orfali, B. (ed.). 2011. In the Shadow of Arabic: The Centrality of Language to Arabic Culture. Leiden: Brill.

PeÑa, S. 2013. "Which Curiosity? Ibn Ḥazm's Suspicion of Grammarians". In Adang / Fierro / SCHMIDTKE (eds.) 2013: 233-250.

Reuter, T. (ed.). 1995. The New Cambridge Medieval History. Cambridge: Cambridge University Press.

Rizzitano, U. 1975. Storia e cultura nella Sicilia saracena. Palermo: Flaccovio.

— . "Ibn al-Birr". In: Encyclopaedia of Islam, Second Edition, Edited by: P. Bearman, Th. Bianquis, C.E. Bosworth, E. van Donzel, W.P. Heinrichs. Consulted online on 31 October 2017 $<\mathrm{http} / / /$ dx.doi.org/10.1163/1573-3912_islam_SIM_3117>. 


\section{Mirella Cassarino and Antonella Ghersetti}

Versteegh, K. 1997. Landmarks in Linguistic Thought III: The Arabic Linguistic Tradition. London: Routledge.

— . 2013. "Ibn Maḍā̄ al-Qurțubī as a Zāhirī Grammarian". In ADANG / FierRo / SCHMIDTKE (eds.) 2013: 207-232.

— et alii (eds.). 2006-2011. Encyclopedia of Arabic Language and Linguistics. 5 vols. Leiden, Boston: Brill.

- / CARTER, M.G. (eds.). 1990. Studies in the History of Arabic Grammar II: Proceedings of the $2^{\text {nd }}$ Symposium of Arabic Grammar, Nijmegen, 27 April-1 May 1987. Amsterdam/Philadelphia: Benjamins.

Wolfe, R. 1990. “Ibn Maḍā̄ al-Qurțubī’s Kitāb ar-Radd 'alà n-Nuhât: An Historical Misnomer”. In VERSTEEGH \& CARTER (eds.) 1990: 295-306.

(C) Mirella Cassarino, Università degli studi di Catania / Italy Antonella Ghersetti, Università Ca' Foscari Venezia / Italy 4 mirella.cassarino@libero.it | antghers@unive.it 